\title{
TINGKAT KEPUASAN PASIEN RAWAT INAP TERHADAP PELAYANAN KONSELING GIZI DI RUMAH SAKIT PUSAT OTAK NASIONAL
}

\author{
Yessi Marlina $^{1}$, dan Nur Asti Ramadhani ${ }^{1}$ \\ ${ }^{1}$ Jurusan Gizi, Poltekkes Kemenkes Riau, Indonesia \\ Jl. Melur no.103, Sukajadi, Pekanbaru \\ Email : yessi.marlina@pkr.ac.id
}

\begin{tabular}{l} 
Article Info \\
\hline Article history: \\
Received January $14^{\text {th }}, 2021$ \\
Revised February $21^{\text {th }}, 2021$ \\
Accepte March $25^{\text {th }}, 2021$
\end{tabular}

\section{Keyword:}

Nutrition Counseling;

Nutrition Service; Satisfaction Rate

\section{Kata Kunci :}

Konseling Gizi; Pelayanan Gizi; Tingkat Kepuasan

\begin{abstract}
Background : Nutrition counseling is a two-way communication process between counselor and client to help clients recognize and overcome nutritional problems. Patients are entitled to receive a good quality nutrition counseling since that is an integral part in accelerating the patient's healing process. The purpose of this study was to determine the level of satisfaction of patients with nutrition counseling services at the Rumah Sakit Pusat Otak Nasional.
\end{abstract}

Methods : This research was a descriptive study with cross sectional design. The sample technique used accidental sampling with total samples were 30 patients from second and third-grade room. The level of satisfaction included counseling service time, attitudes and characteristics of counselor, materials of counseling and media of counseling. Response options were based on a five-point Likert scale from "strongly satisfied" to "strongly unsatisfied".

Results : The results showed that the satisfaction rate with counseling service time was $77,06 \%$ (satisfied), attitudes and characteristics of counselor was $84,26 \%$ (very satisfied), counseling material was $78,13 \%$ (satisfied), and the use of media during the nutritional counseling process was $65,86 \%$ (satisfied).

Conclusion : The satisfaction rate with nutritional counseling services at the Rumah Sakit Pusat Otak Nasional is satisfied $(73,33 \%)$.

\begin{abstract}
ABSTRAK
Latar Belakang : Konseling gizi merupakan suatu proses komunikasi dua arah antara konselor dan klien untuk membantu klien mengenali dan mengatasi masalah gizi. Pasien berhak mendapatkan konseling gizi yang berkualitas karena konseling gizi adalah bagian integral dalam mempercepat proses penyembuhan pasien. Tujuan penelitian ini adalah untuk mengetahui tingkat kepuasan pasien rawat inap terhadap pelayanan konseling gizi di Rumah Sakit Pusat Otak Nasional Jakarta.

Metode : Jenis penelitian adalah deskriptif dengan disain cross sectional. Teknik pengambilan sampel yang digunakan adalah accidental sampling dengan jumlah sampel sebanyak 30 orang, yang merupakan pasien rawat inap di ruang perawatan kelas 2 dan 3. Variabel kepuasan yang diteliti meliputi waktu pelayanan konseling, sikap dan karakteristik konselor, materi konseling dan media konseling yang diperoleh melalui wawancara menggunakan kuisioner dengan skala Likert.
\end{abstract}

Hasil : Hasil penelitian menunjukkan bahwa tingkat kepuasan 
terhadap aspek waktu pelayanan sebesar 77,06\% (memuaskan), sikap dan karakteristik konselor sebesar 84,26\% (sangat memuaskan), materi konseling sebesar 78,13\%(memuaskan), dan penggunaan media selama konseling sebesar 65,86\% (memuaskan).

Kesimpulan : Tingkat kepuasan pasien rawat inap terhadap pelayanan konseling gizi di Rumah Sakit Pusat Otak Nasional adalah memuaskan $(73,33 \%)$.

\section{PENDAHULUAN}

Konseling gizi merupakan suatu proses komunikasi dua arah antara konselor dan klien untuk membantu klien mengenali dan mengatasi masalah gizi (Supariasa 2012). Konseling gizi adalah kegiatan pendidikan yang dilakukan dengan cara menyebarkan pesan, menanamkan keyakinan, sehingga masyarakat tidak saja sadar, tahu dan mengerti, tetapi juga mau dan bisa melakukan suatu anjuran yang ada hubungannya dengan kesehatan. Konseling gizi berperan untuk membantu klien/pasien dalam mengubah perilaku yang positif hubungannya dengan makanan dan gizi, mengenali permasalahan kesehatan dan gizi yang dihadapi, mengatasi masalah, mendorong klien untuk mencari cara pemecahan masalah, mengarahkan klien untuk memilih cara pemecahan masalah yang paling sesuai dan membantu proses penyembuhan penyakit melalui perbaikan gizi klien (PERSAGI 2018).

Pasien berhak mendapatkan konseling gizi yang berkualitas karena konseling gizi adalah bagian integral dalam mempercepat proses penyembuhan pasien. Konseling gizi yang berkualitas juga dapat meningkatkan efektivitas dan efisiensi sumber daya serta memberikan kepuasan kepada pasien. Pasien di rumah sakit mempunyai kebutuhan, pilihan, kepentingan, keunikan dan sensitivitas yang berbeda-beda, sehingga konseling gizi sebaiknya disesuaikan dengan kebutuhan, kepentingan dan harapan pasien (Iwaningsih 2005).

Hasil penelitian tentang faktor-faktor yang berhubungan dengan kepuasan pasien rawat inap terhadap pelaksanaan konseling gizi di Rumah Sakit Holistic Purwakarta, menunjukkan bahwa mutu konseling gizi rata-rata $99,7 \%$ (sangat memuaskan) yang terdiri dari aspek penampilan sebesar $100 \%$, prosedur pelayanan sebesar 99,7\%, dan sikap pelayanan petugas sebesar 96,7\%, tingkat kepuasan terhadap konselor $100 \%$ puas, metode $89,7 \%$ puas, materi $98,5 \%$ puas, media $91,2 \%$ puas, tempat $89,7 \%$ puas, lama konseling gizi $80,9 \%$ puas, dan terhadap frekuensi kunjungan ahli gizi (konselor) 66,2\% puas (Astuti, Yani, and Lisnawati 2017).

Rumah Sakit Pusat Otak Nasional merupakan rumah sakit rujukan khusus neurologi di Indonesia. Berdasarkan laporan Rencana Bisnis dan Anggaran (RBA) Rumah Sakit Pusat Otak Nasional Tahun 2018, jumlah pasien pada kunjungan rawat jalan sebanyak 58.982 pasien, kunjungan pasien gawat darurat sebanyak 4.735 pasien dan hari perawatan rawat inap sebanyak 30.316 pasien. Perbedaan pelayanan kesehatan di Rumah Sakit Pusat Otak Nasional dengan rumah sakit lainnya yaitu pelayanan yang terintegrasi pada kasus penyakit otak. Selain pelayanan yang terintegrasi, Rumah Sakit Pusat Otak Nasional juga menyiapkan alat navigasi mutakhir seperti Computerized Tomography (CT) scan 250 lapis yang berfungsi untuk memberikan hasil pemindaian yang lebih presisi dibandingkan alat pendahulunya. Penanganan pasien di Rumah Sakit Pusat Otak Nasional dilakukan dengan cepat dan segera, hal ini sangat berpengaruh bagi kemungkinan harapan hidup pasien stroke. Dengan pemaparan yang telah di sampaikan, penulis ingin mengetahui tingkat kepuasan pasien rawat inap terhadap pelayanan konseling gizi di Rumah Sakit Pusat Otak Nasional Jakarta.

\section{METODE PENELITIAN}

Penelitian ini merupakan jenis penelitian deskriptif dengan desain cross sectional. Populasi dalam penelitian ini adalah semua pasien rawat inap kelas II dan kelas III yang mendapatkan pelayanan konseling gizi di Rumah Sakit Pusat Otak Nasional Jakarta. Teknik pengambilan sampel yang digunakan adalah Accidental Sampling.

Instrumen yang digunakan dalam penelitian ini adalah kuesioner yang berisi pertanyaan yang jawabannya berupa skor tingkat kepuasan pasien terdiri dari aspek waktu pelayanan konseling, sikap dan karakteristik konselor, materi konseling dan media konseling. Analisis data dilakukan untuk mengetahui tingkat kepuasan pasien rawat inap terhadap pelayanan konseling gizi. 


\section{HASIL DAN PEMBAHASAN PENELITIAN}

Tabel 1. Distribusi Karakteristik Responden

\begin{tabular}{|c|c|c|}
\hline Karakteristik & $\mathbf{n}$ & Persentase $(\%)$ \\
\hline \multicolumn{3}{|l|}{ Umur Responden : } \\
\hline \multicolumn{3}{|l|}{$9-19$ tahun } \\
\hline $20-30$ tahun & 3 & 10 \\
\hline $31-41$ tahun & 1 & 3,3 \\
\hline $42-52$ tahun & 3 & 10 \\
\hline $53-63$ tahun & 11 & 36,7 \\
\hline $64-74$ tahun & 7 & 23,3 \\
\hline $9-19$ tahun & 5 & 16,7 \\
\hline \multicolumn{3}{|l|}{ Jenis Kelamin : } \\
\hline Laki-laki & 12 & 40 \\
\hline Perempuan & 18 & 60 \\
\hline \multicolumn{3}{|l|}{ Pekerjaan : } \\
\hline Ibu Rumah Tangga & 12 & 40 \\
\hline Pegawai Swasta & 4 & 13,3 \\
\hline Wiraswasta & 3 & 10 \\
\hline Pensiunan & 4 & 13,3 \\
\hline Pelajar/Mahasiswa & 1 & 3,3 \\
\hline Tidak diketahui & 5 & 16,7 \\
\hline Lain-lain & 1 & 3,3 \\
\hline \multicolumn{3}{|l|}{ Pendidikan Terakhir : } \\
\hline Belum tamat SD & 1 & 3,3 \\
\hline Tamat SMP & 5 & 16,7 \\
\hline Tamat SMA & 14 & 46,7 \\
\hline Diploma & 2 & 6,7 \\
\hline Sarjana & 3 & 10 \\
\hline Tidak diketahui & 5 & 16,7 \\
\hline \multicolumn{3}{|l|}{ Jenis Konsultasi: } \\
\hline Diet Makanan Cair & 2 & 6,7 \\
\hline Diet Makanan Lunak & 1 & 3,3 \\
\hline Diet Diabetes Mellitus & 2 & 6,7 \\
\hline Diet Diabetes Mellitus, Rendah Garam & 2 & 6,7 \\
\hline Diet Diabetes Mellitus, Rendah Lemak & 2 & 6,7 \\
\hline Diet Diabetes Mellitus, Rendah Purin & 1 & 3,3 \\
\hline Diet Rendah Lemak & 1 & 3,3 \\
\hline Diet Rendah Garam & 3 & 10 \\
\hline Diet Rendah Garam, Rendah Lemak & 1 & 3,3 \\
\hline Diet Rendah Garam, Rendah Purin & 1 & 3,3 \\
\hline Diet Rendah Purin, Karbohidrat Terbatas & 1 & 3,3 \\
\hline Diet Rendah Kolesterol & 1 & 3,3 \\
\hline Diet Tinggi Protein & 1 & 3,3 \\
\hline Diet Tinggi Energi Tinggi Protein & 1 & 3,3 \\
\hline Diet Gizi Seimbang & 10 & 33,3 \\
\hline
\end{tabular}

Kepuasan bersifat subjektif dan merupakan hasil reaksi afeksi (penilaian perasaan), meskipun objek yang dinilai adalah sama (Utama, 2003). Perbedaan reaksi ini ditentukan oleh akrakteristik individu, seperti suku bangsa dengan nilai budaya yang dianut, pendidikan, umur, jenis kelamin, pekerjaan, status perkawinan, dan pendapatan (Kurniawan \& Intiasari, 2012).

Jenis konsultasi yang paling banyak diterima responden adalah mengenai diet gizi seimbang yaitu sebanyak 10 orang $(33,3 \%)$. Hal ini dikarenakan mayoritas responden merupakan pasien yang dirawat karena operasi tumor otak atau pasien yang tidak mempunyai penyakit komplikasi. Jenis konsultasi terbanyak kedua yang 
diterima responden adalah diet Rendah Garam. Konsultasi yang diberikan oleh konselor sesuai dengan kebutuhan maupun kondisi penyakit pasien.

Tabel 2. Distribusi Tingkat Kepuasan Pasien Berdasarkan Kategori Waktu Pelayanan Konseling

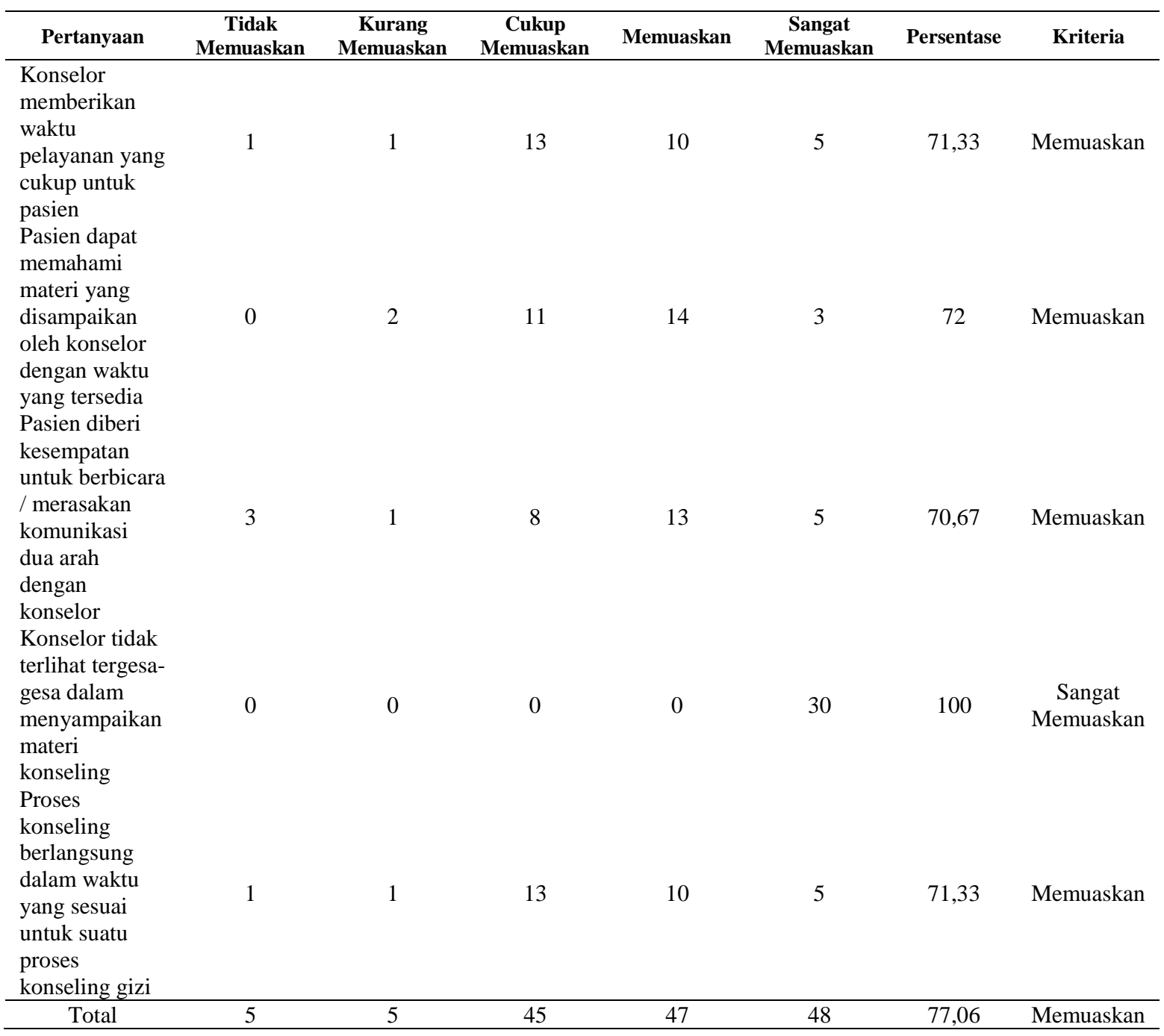

Tabel 2. menunjukkan bahwa waktu pelayanan konseling mempunyai tingkat kepuasan sebesar 77,06\% yang termasuk dalam kriteria memuaskan. Masih ada pasien yang merasa tidak diberi kesempatan untuk berbicara dan hanya mendengarkan apa yang disampaikan oleh konselor. Hal ini belum sesuai dengan syarat konseling menurut (Cornelia et al. 2016) yaitu hubungan atau kedudukan antara klien dan konselor sejajar. Pasien dapat mengutarakan pendapat kepada konselor sehingga terjadi komunikasi dua arah antara konselor dan pasien.

Pelaksanaan konseling dilakukan pada saat 1 atau 2 hari sebelum pasien pulang. Konselor mendatangi ruang rawat inap pasien dengan membawa media konseling seperti leaflet dan satuan penukar. Sebelum menyampaikan materi konseling, konselor menyapa pasien terlebih dahulu, memperkenalkan diri dan menjelaskan tujuan serta menanyakan keluhan pasien yang berkaitan dengan makanan. Selanjutnya konselor menjelaskan tentang diet pasien, tujuan diet, syarat diet, makanan yang dianjurkan dan tidak dianjurkan, cara pengolahan makanan, serta cara mengganti bahan makanan yang memiliki kandungan gizi yang sama dengan menggunakan bahan penukar. Konselor memberikan pasien kesempatan berbicara maupun bertanya, namun ada pasien yang merasa tidak paham dengan apa yang disampaikan oleh konselor sehingga hanya diam dan mendengarkan apa yang disampaikan oleh konselor. 
Konseling gizi yang dilakukan di rumah sakit tersebut umumnya berlangsung selama \pm 30-45 menit. Sebagian besar $(71,33 \%)$ pasien merasa puas terhadap waktu konseling yang diberikan ( \pm 30 menit). Lama waktu konseling tergantung dari kasus yang ditangani dan tidak dapat ditentukan secara pasti. Lama atau waktu yang baik untuk suatu proses konseling adalah selama 30-60 menit (Astuti, Yani, and Lisnawati 2017). Penelitian yang dilakukan oleh Astuti et.al (2017) menunjukkan bahwa 96,9\% responden merasa puas terhadap lama konseling, 3,1\% responden merasa kurang puas sebesar dan $0,0 \%$ responden merasa tidak puas. Hal ini karena responden merasa puas terhadap lama konseling ( \pm 30 menit) sehingga responden dapat berdiskusi dengan konselor lebih leluasa.

Tabel 3. Distribusi Tingkat Kepuasan Pasien Berdasarkan Kategori Sikap dan Karakteristik Konselor

\begin{tabular}{|c|c|c|c|c|c|c|c|}
\hline Pertanyaan & $\begin{array}{c}\text { Tidak } \\
\text { Memuaskan }\end{array}$ & $\begin{array}{c}\text { Kurang } \\
\text { Memuaskan }\end{array}$ & $\begin{array}{c}\text { Cukup } \\
\text { Memuaskan }\end{array}$ & Memuaskan & $\begin{array}{c}\text { Sangat } \\
\text { Memuaskan }\end{array}$ & Persentase & Kriteria \\
\hline $\begin{array}{l}\text { Konselor } \\
\text { berpenampilan } \\
\text { rapi dan bersih }\end{array}$ & 0 & 0 & 1 & 14 & 15 & 89,33 & $\begin{array}{c}\text { Sangat } \\
\text { Memuaskan }\end{array}$ \\
\hline $\begin{array}{l}\text { Konselor } \\
\text { bersikap sopan } \\
\text { dan ramah }\end{array}$ & 0 & 0 & 1 & 15 & 14 & 88,67 & $\begin{array}{c}\text { Sangat } \\
\text { Memuaskan }\end{array}$ \\
\hline $\begin{array}{l}\text { Konselor } \\
\text { mendengarkan } \\
\text { keluhan } \\
\text { penyakit yang } \\
\text { diderita pasien }\end{array}$ & 0 & 0 & 5 & 12 & 13 & 85,33 & $\begin{array}{c}\text { Sangat } \\
\text { Memuaskan }\end{array}$ \\
\hline $\begin{array}{l}\text { Konselor } \\
\text { memberikan } \\
\text { solusi dalam } \\
\text { konseling }\end{array}$ & 0 & 0 & 7 & 19 & 4 & 78 & Memuaskan \\
\hline $\begin{array}{l}\text { Konselor } \\
\text { melayani } \\
\text { dengan sikap } \\
\text { meyakinkan } \\
\text { sehingga } \\
\text { pasien merasa } \\
\text { aman }\end{array}$ & 0 & 0 & 4 & 22 & 4 & 80 & $\begin{array}{c}\text { Sangat } \\
\text { Memuaskan }\end{array}$ \\
\hline Total & 0 & 0 & 18 & 82 & 50 & 84,26 & $\begin{array}{c}\text { Sangat } \\
\text { Memuaskan }\end{array}$ \\
\hline
\end{tabular}

Tabel 3. menunjukkan bahwa pelayanan konseling gizi dari aspek sikap dan karakteristik konselor mempunyai tingkat kepuasan sebesar 84,26\% (sangat memuaskan). Konselor dalam melakukan konseling gizi bersikap ramah dan sopan, mendengarkan keluhan pasien, memberikan solusi untuk pemecahan masalah pasien, dan memberikan informasi yang relevan kepada pasien. Hal ini sejalan dengan penelitian yang dilakukan oleh Kristina (2016) yang menunjukkan bahwa 72,78\% responden merasa puas terhadap sikap dan karakteristik konselor. Konselor berbicara menggunakan bahasa yang sopan, selalu menyambut pasien dengan ramah dan menanyakan keluhan pasien saat ini. Konselor dianggap komunikatif dan memiliki rasa kepedulian yang tinggi. Simbolon dan Siringo-ringo (2017) mengatakan bahwa emphaty merupakan ketersediaan pemberi layanan untuk memberikan perhatian secara pribadi kepada pasien. Konselor berperan untuk membantu klien dan pasien dalam mengubah perilaku positif hubungannya dengan makanan dan gizi, mengenali permasalahan kesehatan dan gizi yang dihadapi, mendorong klien untuk mencari cara pemecahan masalah, mengarahkan klien untuk memilih cara pemecahan masalah yang paling sesuai dan membantu proses penyembuhan penyakit melalui perbaikan gizi klien (Astuti, Yani, and Lisnawati 2017). 
Tabel 4. Distribusi Tingkat Kepuasan Pasien Berdasarkan Kategori Materi Konseling

\begin{tabular}{|c|c|c|c|c|c|c|c|}
\hline Pertanyaan & $\begin{array}{c}\text { Tidak } \\
\text { Memuaskan }\end{array}$ & $\begin{array}{c}\text { Kurang } \\
\text { Memuaskan }\end{array}$ & $\begin{array}{c}\text { Cukup } \\
\text { Memuaskan }\end{array}$ & Memuaskan & $\begin{array}{c}\text { Sangat } \\
\text { Memuaskan }\end{array}$ & Persentase & Kriteria \\
\hline $\begin{array}{l}\text { Konselor } \\
\text { memberi } \\
\text { konseling } \\
\text { sesuai dengan } \\
\text { penyakit } \\
\text { pasien / } \\
\text { kebutuhan } \\
\text { pasien }\end{array}$ & 0 & 0 & 8 & 16 & 6 & 78,67 & Memuaskan \\
\hline $\begin{array}{l}\text { Konselor } \\
\text { memberitahu } \\
\text { jenis diet, } \\
\text { tujuan diet, } \\
\text { dan syarat } \\
\text { diet secara } \\
\text { lengkap }\end{array}$ & 0 & 0 & 9 & 15 & 6 & 78 & Memuaskan \\
\hline $\begin{array}{l}\text { Konselor } \\
\text { mempunyai } \\
\text { kemampuan } \\
\text { dan } \\
\text { pengetahuan } \\
\text { dalam } \\
\text { menentukan } \\
\text { jenis diet } \\
\text { dengan cukup } \\
\text { baik }\end{array}$ & 0 & 0 & 6 & 20 & 4 & 78,67 & Memuaskan \\
\hline $\begin{array}{l}\text { Konselor } \\
\text { memberikan } \\
\text { konseling } \\
\text { dengan } \\
\text { menggunakan } \\
\text { bahasa } \\
\text { sederhana dan } \\
\text { mudah di } \\
\text { mengerti }\end{array}$ & 0 & 0 & 8 & 16 & 6 & 78,67 & Memuaskan \\
\hline $\begin{array}{l}\text { Konselor } \\
\text { mampu } \\
\text { menjawab } \\
\text { semua } \\
\text { pertanyaan } \\
\text { dengan tepat }\end{array}$ & 0 & 0 & 10 & 15 & 5 & 76,67 & Memuaskan \\
\hline Total & 0 & $\mathbf{0}$ & 41 & 82 & 27 & 78,13 & Memuaskan \\
\hline
\end{tabular}

Tabel 4. menunjukkan bahwa pelayanan konseling gizi dari aspek materi konseling mempunyai tingkat kepuasan sebesar 78,13\% (memuaskan). Konselor dianggap memiliki pengetahuan dan kemampuan dalam menentukan jenis diet dengan menggunakan bahasa sederhana dan mudah dimengerti. Cornelia et al. (2016) mengatakan bahwa seorang konselor harus memberikan informasi yang relevan sesuai dengan yang dibutuhkan oleh klien dan menggunakan bahasa yang sederhana sehingga mudah dipahami. Konselor menyampaikan materi sesuai dengan permasalahan pasien. Penyampaian materi dilakukan bertahap, diawali dengan hal-hal yang mudah hingga hal yang rumit, dari hal yang bersifat umum hingga khusus. Hal yang disampaikan konselor terdiri dari jenis diet, tujuan diet, syarat diet, makanan yang dianjurkan dan tidak dianjurkan, jumlah porsi serta bahan penukar yang dapat digunakan oleh pasien untuk menjalankan diet di rumah. 
Tabel 5. Distribusi Tingkat Kepuasan Pasien Berdasarkan Kategori Media Konseling

\begin{tabular}{|c|c|c|c|c|c|c|c|}
\hline Pertanyaan & $\begin{array}{c}\text { Tidak } \\
\text { Memuaskan }\end{array}$ & $\begin{array}{c}\text { Kurang } \\
\text { Memuaskan }\end{array}$ & $\begin{array}{c}\text { Cukup } \\
\text { Memuaskan }\end{array}$ & Memuaskan & $\begin{array}{c}\text { Sangat } \\
\text { Memuaskan }\end{array}$ & Persentase & Kriteria \\
\hline $\begin{array}{l}\text { Konselor } \\
\text { menggunakan } \\
\text { food model } \\
\text { dalam } \\
\text { memberikan } \\
\text { konseling }\end{array}$ & 30 & 0 & 0 & 0 & 0 & 20 & $\begin{array}{c}\text { Kurang } \\
\text { Memuaskan }\end{array}$ \\
\hline $\begin{array}{l}\text { Konselor } \\
\text { menggunakan } \\
\text { bahan } \\
\text { makanan } \\
\text { penukar } \\
\text { dalam } \\
\text { memberikan } \\
\text { konseling }\end{array}$ & 0 & 0 & 10 & 16 & 4 & 76 & Memuaskan \\
\hline $\begin{array}{l}\text { Konselor } \\
\text { menggunakan } \\
\text { dan } \\
\text { menjelaskan } \\
\text { isi leaflet } \\
\text { dalam } \\
\text { memberikan } \\
\text { konseling }\end{array}$ & 0 & 0 & 8 & 18 & 4 & 77,33 & Memuaskan \\
\hline $\begin{array}{l}\text { Konselor } \\
\text { memberikan } \\
\text { leaflet pada } \\
\text { pasien } \\
\text { sebagai } \\
\text { panduan } \\
\text { dalam } \\
\text { melakukan } \\
\text { diet }\end{array}$ & 0 & 0 & 7 & 19 & 4 & 78 & Memuaskan \\
\hline $\begin{array}{l}\text { Pasien dapat } \\
\text { menggunakan } \\
\text { fasilitas untuk } \\
\text { mengetahui } \\
\text { status gizinya }\end{array}$ & 0 & 0 & 8 & 17 & 5 & 78 & Memuaskan \\
\hline Total & 30 & $\mathbf{0}$ & 33 & 70 & 17 & 65,86 & Memuaskan \\
\hline
\end{tabular}

Tabel 5. menunjukkan bahwa pelayanan konseling gizi dari aspek media konseling mempunyai tingkat kepuasan sebesar 65,86\% (memuaskan). Angka tingkat kepuasan pasien ini termasuk dalam nilai yang rendah dikarenakan ada beberapa konselor yang tidak menggunakan bantuan food model dalam memberikan konseling, melainkan hanya menggunakan satuan penukar dan leaflet sebagai media dalam konseling. Manfaat media konseling seperti alat peraga adalah untuk memperjelas pesan-pesan yang akan disampaikan dan juga dapat menambah efektivitas proses pendidikan dan konseling gizi. Namun, dalam hal ini penggunaan food model dalam pelaksanaan konseling gizi untuk pasien rawat inap dianggap kurang efektif dan efisien oleh konselor. Menurut Cornelia et al. (2016) beberapa media yang diperlukan untuk suatu proses konseling gizi yaitu food model dan contoh makanan segar, formulir-formulir (konsumsi makanan, pola makan, asupan zat gizi, konseling gizi, pencatatan dan pelaporan), leaflet diet, daftar bahan makanan penukar dan buku-buku pedoman tatalaksana program (ASI, Gizi Buruk, Xeroftalmia, Diabetes Mellitus, dll). Berdasarkan pengamatan, konseling gizi pada pasien rawat inap hanya menggunakan leaflet dan satuan penukar. Leaflet dan satuan penukar hanya diberikan pada pasien pulang. 


\section{KESIMPULAN}

Kesimpulan dalam penelitian ini adalah tingkat kepuasan pasien terhadap waktu pelayanan konseling gizi sebesar 77,06\% (memuaskan), tingkat kepuasan pasien terhadap sikap dan karakteristik konselor pada layanan konseling gizi sebesar 84,26\% (sangat memuaskan), tingkat kepuasan pasien terhadap materi konseling gizi yang diberikan di rumah sakit sebesar 78,13\% (memuaskan),tingkat kepuasan pasien terhadap penggunaan media selama proses konseling gizi sebesar 65,86\% (memuaskan).

\section{DAFTAR PUSTAKA}

Astuti, Ipah Sri, Ahmad Yani, and Naintina Lisnawati. 2017. "Faktor-Faktor Yang Berhubungan Dengan Kepuasan Pasien Rawat Inap Terhadap Pelaksanaan Konseling Gizi Di Rumah Sakit Holistic Purwakarta." Journal of Holistic and Health Sciences 1(1): 1-12.

Cornelia et al. 2016. Konseling Gizi. Jakarta: Penebar Plus.

Iwaningsih, Sri. 2005. "Pengawasan Dan Pengendalian Mutu Dalam Pelayanan Gizi Di Rumah Sakit.” In Dewan Pimpinan Pusat Persatuan Ahli Gizi Indonesia (Persagi), Bali, 7-10.

Kristina. 2016. Tingkat Kepuasan Masyarakat Terhadap Layanan Konseling Gizi Di Puskesmas Sidomulyo Pekanbaru. Pekanbaru: Poltekkes Kemenkes Riau.

Kurniawan, A., \& Intiasari, A. D. (2012). Pengaruh Karakteristik Pasien terhadap Indeks Kepuasan Masyarakat tentang Pelayanan Rawat Jalan Puskesmas Banyumas. Jurnal Kesmasindo, 5(2), 169-179. Retrieved from h p://jos.unsoed.ac.id/index.php/kesma sindo/article/view/43/41

PERSAGI. 2018. Konseling Gizi: Proses Komunikasi, Tata Laksana, Serta Aplikasi Konseling Gizi Pada Berbagai Diet. Jakarta: Penebar Plus Rineka Cipta. https://aipgi.org/home/wpcontent/uploads/2019/04/Starkom-NUTRISIONIS.pdf.

Simbolon, P., \& Siringo-ringo, M. (2017). Kepuasan Pasien Imobilisasi dalam Pemenuhan Personal Hygiene Rumah Sakit santa Elisabeth Medan. Jurnal Kesehatan Vokasional, 2(2). h ps://doi.org/h ps://doi.org/10.22146/j kesvo.30335

Supariasa, I Dewa Nyoman. 2012. "Pendidikan Dan Konsultasi Gizi."

Utama, S. (2003). Memahami Fenomena Kepuasan Pasien Rumah Sakit. Universitas Sumatera Utara. 